\title{
METHOD OF STUDIYING INTERPERSONAL FEEDBACK \\ IN BUSINESS COMMUNICATION
}

\author{
A. Belov ${ }^{1}$ \\ DOI: http://doi.org/10.15350/L_26/9/4
}

\begin{abstract}
In the article is scrutinized the problem of analyzing the feedback supply in the context of business communication between company employees and customers. A brief theoretical overview of feedback problems in interpersonal communication is provided, as well as experience in the development of psychological analysis methods of the feedback with the example of the grid content analysis of the dialogue partners statements.
\end{abstract}

Keywords: Business communication, feedback, interpersonal feedback, dialogue, employee, customer, content analysis, feedback classification.

At the present time the view of business as a partnership system is considered to be the most promising. In this regard, business communication studies become of particular relevance and importance, which reveals the communication partners relationship specifics and performance characteristics of their interaction. In soviet and Russian social psychology were developed theoretical propositions about the functions, role and structure of communication (G.M.Andreeva), the kinds of communication and feedback supply (L.A.Petrovskaya), the feedback characteristics (O.V.Soloveva). Various experimental studies have investigated the aspects of feedback in interpersonal communication (N.V.Antonova, A.B. Belov, N.S. Zhuravleva, M.A. Ladionenko, E.N. Stremousova et al.). On this basis, we developed an author's method of studying the feedback in business communication.

According to the methods for transmitting feedback can be divided into direct and hardware, mediated by various technical means (camera, tape recorder, video camera, a movie camera, and so on). By type of device feedback can be divided into communicator-subject and the communicator-object. In the first case the feedback source is people (group of people), and in this sense, they play the rope of subject, and in the second case - any other physical reality world. Further, we consider the communicator-subject feedback. For this type, three main types can be distinguished, namely^ the feedback system "the individual - the individual", "individual - group" and "group - a group" [7]. From these three possible combinations precisely the type of "individual - the individual" complies with our study objectives.

Social feedback such as "individual-individual" is usually referred to as interpersonal feedback. It plays a dominant role in the socio-psychological training.

${ }^{1}$ Andrew Belov, PhD Student, Moscow State University, Russia. 
According to the means of transmission, it can be divided into verbal and nonverbal. Also, the feedback can combine evaluation and interpretive components, supplied in the form of advice, suggestions, requests [9]. In addition to the forms, feedback classification can be carried out on the content: about the behavior, psychological state, the result of the action, etc. [4].

As we are studying the situation of business communication in the service company it will supply a priority to intentional verbal feedback, leading to the establishment of trust between the client and the company employee and allowing partners to progress in solving their common business objectives.

The study involved 27 staff members ( 20 men and 7 women), employees of the Russian service company (which sells and services vehicles) between the ages of 20 and 55 years and withexperience in the specialty for at least 1 year. Communication with customers is a major part of their work. Also, the study involved 32 clients of the company: 22 men and 10 women aged from 20 to 66 years.

Surveillance of employees communicating with customers was conducted. Were recorded on tape ten dialogues each employee with customers. To eliminate the influence of factors previously formed personal relationships, were recorded conversations only with those customers who were not previously familiar to employees.

For the analysis of the formal and substantive statements by members during the actual interaction with the client was used a categorical grid developed on the basis of L.A. Petrovskaya approach [8], in a modified in accordance with the purposes of this study variant.

Table 1

Example of a content analysis grid for feedback in business communication

\begin{tabular}{|l|l|l|}
\hline Code & Category & Examples \\
\hline 2 & Feedback & $\begin{array}{l}\text { We've already had two such cases in two } \\
\text { days. You're well done, that as soon as no- } \\
\text { ticed the oil leak, come to us. }\end{array}$ \\
\hline 2B & Descriptive & $\begin{array}{l}\text { I am very glad that you are so lucky with } \\
\text { the car }\end{array}$ \\
\hline 2B & Evaluative & $\begin{array}{l}\text { You did the right thing as soon as noticed } \\
\text { oil leakage came to us. }\end{array}$ \\
\hline 2C & Evaluative \& Interpreting & $\begin{array}{l}\text { You are an educated man, you know, that } \\
\text { where thin, there and tear. }\end{array}$ \\
\hline 2D & Advice & $\begin{array}{l}\text { It is better to come in the next time, we will } \\
\text { then TO1 and TO2 will hold together. }\end{array}$ \\
\hline 2E & Feedback emotional sign & $\begin{array}{l}\text { You're well done, that as soon as noticed oil } \\
\text { leakage came to us. }\end{array}$ \\
\hline 2Ea & Positive + & You spend time my and your in vain. \\
\hline 2Eb & Negative - & $\begin{array}{l}\text { All papers are in order, you have arrived in } \\
\text { time. }\end{array}$ \\
\hline 2Ec & Neutral & $\begin{array}{l}\text { You're well done, that as soon as noticed oil } \\
\text { leakage came to us. }\end{array}$ \\
\hline 2F & $\begin{array}{l}\text { Argument-based } \text { (from } \\
\text { above) }\end{array}$ & \\
\hline
\end{tabular}


Feedback broadly aimed at the content of the message was supplied in all the observed dialogues between customers and employees. Here are some examples:

Customer: Do you have a cabin light bulb?

An employee of the company: What car accessories set do you posess?

Client: Standard one with velour seats.

An employee of the company: Yes, there is one for this configuration.

Feedback in the narrow sense (personal), which is characterized by an orientation on the identity or nature of the communication, was not always observed. Here are some examples of using the feedback in the narrow sense:

An employee of the company: What is your problem with oil dribble?

Client: Here, look, there are very few left, topped up with a liter per 100 kilometers.

An employee of the company: Good job for you, that as soon as you have noticed you came to us. You're just in time: avoid large and expensive repairs (appraisal, positive, reasoned feedback).

An analysis of the employees statements structure in the process of business communicating with customers has shown a significant predominance of substantive statements aimed at the client itself, a car failure, other employees $(60 \%$ of all statements) of the treatment (20\%) and the actual feedback (16\%). In a small number of attributive judgments (4\%) were present in the dialogues. Among meaningful utterances the greatest number belongs to statements pointing out the working process $(30 \%)$. They are more than statements aimed at the client $(25 \%)$, automobile (11\%), self $(10 \%)$, a fault with vehicle $(10 \%)$ at spare parts and supplies (7\%), staff technical center (6\%). Many of these statements are included in the meaningful semantic system applications and requirements, for example, revealing more detailed service rules $30 \%$ of the total number of statements designed to workflow) and organizational - business procedures $(70 \%)$.

Feedback of employees are up to $16 \%$ of the total number of sentences. There were all kinds of feedback: descriptive (example: "We've already had two such cases in two days you done that as soon as noticed the oil leak, come to us"), selfdescriptive (example: "I am glad that you are so lucky with the machine "), evaluative (example:" you have done that immediately came to us "), assessment and interpretive (example:" you are an educated man, you know, that where thin, there and tear "), advice (example: "It is better to come in the next time, we will then T01 and T02 will hold together"). Analysis of all statements of employees, giving feedback to clients, demonstrated the predominance of descriptive feedback ( $47 \%$ of the feedback statements by category) on self-descriptive (24\%), evaluative (5.8\%), assessment and interpretive (4.5\%) and a specific form of advice $(16 \%)$.

Intonation, which with was submitted feedback, was mostly neutral on the emotional character ( $84 \%$ of statements relating to the feedback).

Conclusions

The study showed correspondence between developed studying feedback in business communication technique and our research purposes. The developed 
method allows to fully explore the content and feedback forms, to draw conclusions about the nature of the feedback from employees to customers, and to develop practical recommendations to improve the business communication of company employees with customers.

\section{References:}

[1] Andreeva G.M. Social Psychology: A Textbook for high schools. 5th ed., Rev. and ext. Moscow: Aspect Press, 2004.

[2] Antonova N.V. The identity of the teacher and the features of its communication. Doctoral thesys. Psychol. Sciences. Moscow, 1996.

[3] Belov A.B. Socio-psychological characteristics of the client's perception in business communication // Psychological research. 2012. T. 5, N 25. P. 11. URL: http://psystudy.ru (accessed 10.01.2017).

[4] Zhukov Y.M. Communication skills. Moscow: Gardariki, 2004.

[5] Zhuravleva N.S. Methods of delivery of feedback and its effects in the corporate training. Doctoral thesys. Psychol. Sciences. Moscow, 2004.

[6] Ladionenko M.A. Critical feedback: gender factor in its perception. // Psychology of communication: humanity training: Abstracts of the international scientific-practical conference dedicated to the 70th anniversary of the birth of L.A. Petrovskaya. Moscow: Smysl, 2007. P. $40-42$.

[7] Petrovskaya L.A. Competence in communication: Socio-psychological training. Moscow: Pub. MSU, 1989.

[8] Petrovskaya L.A. Feedback as a phenomenon of social and perceptual processes in the group. // Interpersonal perception in the group. / Ed. G.M. Andreeva, A.I.Dontsov. Moscow: Pub. MSU, 1981.

[9] Solovyova O.V. Feedback in interpersonal communication. Moscow: Pub. MSU, 1992.

[10]Stremousova E.N. Characteristics of feedback in personal and business communication in the organization. // Psychology of communication: humanity training: Abstracts of the international scientific-practical conference dedicated to the 70th anniversary of L.A. Petrovskaya. Moscow: Smysl, 2007. P. 50 - 52. 